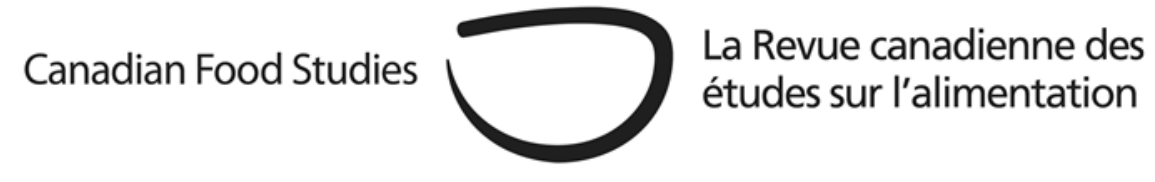

\title{
Editorial
}

\section{A problematic of plenty}

Alexia Moyer, Charles Z. Levkoe, Alyson Holland

(version française à suivre)

$1 \mathrm{~kg}$ beets

$1.5 \mathrm{~kg}$ carrots

1 butternut squash

$0.8 \mathrm{~kg}$ endives

$1.5 \mathrm{~kg}$ onions

$0.8 \mathrm{~kg}$ leeks

$3 \mathrm{~kg}$ potatoes

$0.3 \mathrm{~kg}$ arugula

$1.2 \mathrm{~kg}$ celeriac

2 heads of lettuce

$0.3 \mathrm{~kg}$ mesclun

1 cabbage

Such are the contents of our CSA box this week as Volume 7, Issue 2 of Canadian Food Studies / La Revue canadienne des études sur l'alimentation (CFS/RCÉA) makes its appearance. While the ground begins to harden with the impending winter season, each item is still fresh, its contents ready to chew on. The box and the issue intersect, it seems, in more ways than one.

First, one might consider the individual items on the above list. Green cabbage for one. Ours is destined for the food processor, will keep company with thinly sliced peppers and red onion. There will be a salad, a soup and then perhaps another soup. This is the way of cabbage. Generous and economical. Jennifer O'Connor refers to a cabbage in her review of the 2019-20 Savour exhibition at the Gardener Museum in Toronto, yet it is not meant to be eaten. Though remarkably realistic, this eighteenth century cabbage-shaped, tin-glazed earthenware tureen tells us much about the proclivities and preoccupations of people who made it and others that made use of it. O'Connor takes readers along for a virtual tour through this exploration of how eating, cooking, and dining were reimagined in England and France from the 1650s to the 1790s. 
David Szanto reviews the 'cookbook', The King's Peas, published as companion to this exhibition. He points to the book's achievement in historical documentation while also asking us to think over its glaring tensions - one of which is its tendency to universalize "our modern dining culture" rather than acknowledge its more heterogeneous realities. In "Ditch red meat and dairy, and don't bother with local food", Ryan Katz-Rosene is also troubled by the ill-effects of this same tendency. Here, the universal takes the form of a "global dietary transition" that proposes to save the planet and your health. Katz-Rosene's close inspection, however, finds this one-size-fits-all solution wanting.

The CSA box - colourful, varied and copious - is also a story about a problematic of plenty. Several of the authors in this issue ask: who has access to it, who does not, and how can this imbalance be rectified. Mikiko Terashima et al. are concerned with the physical accessibility of food. Their mixed methods approach - combining spatial analysis with insights gathered from community members in the form of a Photovoice study - provides a deeper understanding of what the journey from home to grocery store and back again looks and feels like. Barbara Parker looks at food access programs designed to support food insecurity in schools. Based on a case study on school food environments in 50 elementary and high schools in a mid-sized city in Ontario, Canada, the article, and its findings, asks us to reimagine a future national food program. As Parker writes, an instrumental approach that medicalizes and moralizes food preparation and consumption fails to take "the complexity of food practices" into account and "misses key pedagogical opportunities within the school food environment". As Laura Lucas and Fabiana Li's photo essay on the Rainbow Community Garden in Winnipeg, Canada reminds us, plenty can be measured widely and variously. A community garden plot's yield is more than just about the consumption of an agricultural product. These plots for newcomer families provide a space to grow culturally appropriate foods, as well as a place for cultural interaction and for intergenerational learning.

In this issue we offer you a fresh crop of book reviews. Ryan Phillips takes Plant-Based Diets for Succulence and Sustainability through its paces; Mindy Jewell Price makes a case for adding Civil Society and Social Movements in Food System Governance to your bookshelves; Amanda Shankland weighs in on Finance or Food? The Role of Cultures, Values, and Ethics in Land use Negotiations; and Rebecca Ellis gives careful consideration to Frontline Farmers: How the National Farmers Union Resists Agribusiness and Creates our New Food Future.

This issue has been crafted by many hands and with its mix of research articles, audiovisual work, event reviews, books reviews and perspectives, it embodies the values of what CFS aims to be: wide-ranging in discipline and subject matter and diverse in the manner in which such work is presented. To our team of contributors, anonymous reviewers, and Associate Editors we extend our gratitude. With thanks to The University of Waterloo Library for its ongoing technical support.

Now that you have perused the contents of this issue, we invite you to taste it for yourselves. Bonne Dégustation. 
$1 \mathrm{~kg}$ de betteraves

$1,5 \mathrm{~kg}$ de carottes

1 courge musquée

$0,8 \mathrm{~kg}$ d'endives

$1,5 \mathrm{~kg}$ d'oignons

$0,8 \mathrm{~kg}$ de poireaux

$3 \mathrm{~kg}$ de pommes de terre

$0,3 \mathrm{~kg}$ de roquette

$1,2 \mathrm{~kg}$ de céleri-rave

2 têtes de laitue

0,3 $\mathrm{kg}$ de mesclun

1 chou

Tel est le contenu de notre panier ASC cette semaine alors que le volume 7, numéro 2 de Canadian Food Studies / La Revue canadienne des études sur l'alimentation (CFS / RCÉA) fait son apparition. Alors que le sol commence à durcir avec la saison hivernale imminente, chaque article est encore frais, son contenu prêt à être dégusté. Le panier et le numéro se croisent, semble-t-il, de plusieurs manières.

Tout d'abord, on pourrait considérer les éléments individuels sur la liste ci-dessus. Chou vert pour un. Le nôtre est destiné au robot culinaire, tiendra compagnie à des poivrons émincés et des oignons rouges. Il y aura une salade, une soupe et peut-être une autre soupe. Les choux sont comme ça. Généreux et économique. Jennifer O'Connor fait référence à un chou dans sa critique de l'exposition Savour 2019-20 au Gardener Museum de Toronto, mais il n'est pas destiné à être mangé. Bien que remarquablement réaliste, cette soupière en faïence émaillée en étain en forme de chou du XVIIIe siècle nous en dit long sur les penchants et les préoccupations des gens qui l'ont fabriquée et de ceux (ou celles) qui l'ont utilisée. O'Connor emmène les lecteurs dans une visite virtuelle à travers cette exploration de la façon dont manger, cuisiner et dîner ont été réinventés en Angleterre et en France entre 1650 et 1790. David Szanto passe en revue le livre de cuisine, The King's Peas, publié comme compagnon de l'exposition du même nom. Il souligne la qualité du livre en terme de documentation historique tout en nous demandant de réfléchir à ses tensions flagrantes - dont l'une est sa tendance à universaliser « notre culture gastronomique moderne » plutôt que de reconnaître ses réalités plus hétérogènes. Dans « Ditch red meat and dairy, and don't bother with local food », Ryan Katz-Rosene est également troublé par les effets néfastes de cette même tendance. Ici, l'universel prend la forme d'une « transition alimentaire globale » qui propose de sauver la planète et votre santé. Cependant, l'inspection minutieuse de Katz-Rosene trouve que cette solution universelle fait défaut.

Le panier ASC — coloré, varié et copieux — est aussi l'histoire d'une problématique d'abondance alimentaire. Plusieurs auteurs de ce numéro demandent: qui y a accès, qui n'y a pas accès et comment corriger ce déséquilibre. Mikiko Terashima et coll. se préoccupent de l'accessibilité physique de la nourriture. Leur approche de méthodes mixtes-combinant l'analyse spatiale avec des informations recueillies auprès des membres de la communauté sous 
la forme d'une étude Photovoice - fournit une compréhension plus profonde de ce à quoi ressemble et comment se ressent le voyage de la maison à l'épicerie et le retour. Barbara Parker examine les programmes d'accès à la nourriture conçus pour contrer l'insécurité alimentaire dans les écoles. Basé sur une étude de cas sur les environnements alimentaires scolaires dans 50 écoles élémentaires et secondaires d'une ville de taille moyenne de l'Ontario, au Canada, l'article et ses conclusions nous demandent de repenser un futur programme alimentaire national. Comme l'écrit Parker, une approche instrumentale qui médicalise et moralise la préparation et la consommation des aliments ne tient pas compte de «la complexité des pratiques alimentaires » et « passe à côté des principales opportunités pédagogiques dans l'environnement alimentaire scolaire ». Comme le rappelle l'essai photo de Laura Lucas et Fabiana Li sur la Rainbow Community Garden à Winnipeg, au Canada, l'abondance alimentaire peuvent être mesurées de manières larges et diverses. Le rendement d'une parcelle de jardin communautaire ne se résume pas à la consommation de ses produits agricoles. Ces parcelles destinées aux familles de nouveaux arrivants offrent un espace pour cultiver des aliments culturellement appropriés, ainsi qu'un lieu d'interaction culturelle et d'apprentissage intergénérationnel.

Dans ce numéro, nous vous proposons aussi un bel assortiment de critiques de livres. Ryan Phillips met à l'épreuve, Plant-Based Diets for Succulence and Sustainability; Mindy Jewell Price plaide en faveur de l'ajout de Civil Society and Social Movements in Food System Governance à vos étagères. Amanda Shankland considère les contributions de Finance or Food? The Role of Cultures, Values, and Ethics in Land use Negotiations; et Rebecca Ellis accorde une attention particulière aux Frontline Farmers: How the National Farmers Union Resists Agribusiness and Creates our New Food Future.

Ce numéro a été rédigé par de nombreuses mains et avec son mélange d'articles de recherche, de travaux audiovisuels, de critiques d'événements, de critiques de livres et de perspectives, il incarne les valeurs de ce que le CFS vise à être: un large éventail de disciplines et de sujets, présentés de façon diversifiés. À notre équipe de contributeurs, de réviseurs anonymes et de rédacteurs associés, nous exprimons notre gratitude. Nous remercions aussi la bibliothèque de l'Université de Waterloo pour son soutien technique.

Maintenant que vous avez parcouru le contenu de ce numéro, nous vous invitons à le goûter par vous-mêmes. Bonne Dégustation. 